\title{
Development, calibration and validation of weighing lysimeters for measurement of evapotranspiration of crops
}

\author{
William Fenner ${ }^{1}$, Rivanildo Dallacort ${ }^{1}$, Cleonir A. Faria Junior ${ }^{1}$, Paulo S. L. de Freitas ${ }^{2}$, \\ Tadeu M. de Queiroz ${ }^{3} \&$ Adalberto Santi $^{1}$ \\ ${ }^{1}$ Universidade do Estado de Mato Grosso. Tangará da Serra, MT, Brasil. E-mail. fennerwilliam@gmail.com (Corresponding author) - ORCID: 0000-0002-3463- \\ 9457; rivanildo@unemat.br - ORCID: 0000-0002-7634-8973; cleonir.junior@hotmail.com- ORCID: 0000-0002-6692-6485; adalbertosanti@unemat.br - ORCID: \\ 0000-0002-0525-4785 \\ ${ }^{2}$ Universidade Estadual de Maringá. Maringá, PR, Brasil. E-mail: pslfreitas@hotmail.com - ORCID: 0000-0001-6663-2797 \\ ${ }^{3}$ Universidade do Estado de Mato Grosso. Barra do Bugres, MT, Brasil. E-mail: tdmqueiroz@unemat.br - ORCID: 0000-0002-1959-7658
}

\begin{abstract}
The evapotranspiration process is critical to studies on the water balance and water demand of crops and can be determined by several methods. A widely-used method, despite its high installation costs, is weighing lysimeters, which consists of a box over a balance connected to a load cell that monitors variations in the soil-water-plant-atmosphere system. The aim of this study was to develop and calibrate six weighing lysimeters (with dimensions of $1.5 \times 1.5 \times 1.2 \mathrm{~m}$ each) by high precision load cells, testing their ability to measure water mass changes in field conditions and cultivated with common bean (Phaseolus vulgaris L.), in the city of Tangará da Serra, in the state of Mato Grosso, Brazil. All lysimeters showed coefficients of determination higher than 0.99, as well as Willmott indexes, correlation and high confidence indexes, indicating that the equipment is suitable for measuring mass variations in water balance and evapotranspiration studies, representing the reality which occurred in the field.
\end{abstract}

Key words: crop coefficient, water balance, lysimetry, water soil engineering

\section{Desenvolvimento, calibração e validação de lisímetros de pesagem para medida de evapotranspiração de culturas}

RESUMO: O processo de evapotranspiração é fundamental em estudos de balanço e demanda hídrica de culturas e sua determinação pode ser realizada por diversos métodos. Um método muito utilizado, apesar de seu custo elevado de instalação são os lisímetros de pesagem, que consistem em uma caixa sobre uma balança, conectados a uma célula de carga que monitora as variações do sistema solo-água-planta-atmosfera. Diante desta temática, este trabalho tem por objetivo a construção e calibração de seis lisímetros de pesagem (com dimensão de 1,5 x 1,5 x 1,2 m cada) por células de carga de alta precisão, testando sua capacidade de medir variações de massa de água em condições de campo e cultivados com feijoeiro comum (Phaseolus vulgaris L.), no município de Tangará da Serra, Estado de Mato Grosso, Brasil. Todos os lisímetros apresentaram coeficientes de determinação superiores a 0,99, assim como os índices de Willmott, correlação e alta confiança, indicando que os equipamentos são adequados para medir variações de massa em estudos de balanço hídrico e evapotranspiração, retratando a realidade ocorrida no campo.

Palavras-chave: coeficiente de cultura, balanço hídrico, lisimetria, engenharia de água e solo 


\section{INTRODUCTION}

Evapotranspiration is a natural process by which water is transferred from the soil and plants to the atmosphere. The determination of evapotranspiration levels can be performed by direct and indirect methods (Howell et al., 1991; Evett et al., 2015). The data obtained from these methods are extremely relevant to the optimization of water resources and energy savings, especially in areas where rainfall has an irregular distribution and in areas where irrigation systems are used (Faria et al., 2006).

Among the methods used for the determination of evapotranspiration, lysimeters are devices that have an isolated structure, where the soil vegetation does not interfere externally. Thus, it is possible to control all inputs and outputs of water into the system. Measurement accuracy depends on factors such as the quality of equipment installation, calibration and boundary area. Regarding the boundary area, the vegetation should have the same characteristics (height and leaf area) as the vegetation within the lysimeters. They are also used in the validation of evapotranspiration estimation methods (Faria et al., 2006; Carvalho et al., 2007; Bryla et al., 2010).

Lysimeters have been developed for over 300 years and consist of tanks filled with soil that measure soil water balance in a soil-plant-atmosphere system (Howell et al., 1991). With the advancement of electronics, more accurate and sensitive sensors (load cells) have been developed, allowing an accurate determination of water mass balance in addition to data storage systems, thereby facilitating the work and the monitoring of lysimeters (Faria et al., 2006; Evett et al., 2015). Calibration entails establishing a relation between the electrical signal, the mass of the set and the system linearity (Faria et al., 2006; Cavalcante Júnior et al., 2013).

Several studies have been conducted with the aim of determining the water consumption of various crops, such as Lippia sidoide (Lopes et al., 2011), sunflower (López-Urrea et al., 2012) and Quinoa (Talebnejad \& Sepaskhah, 2015). Matušek et al. (2016) affirmed that lysimeters can be applied in research in the areas of agriculture, environment, hydrology and climate change, being a unique tool for the monitoring of interactions between environmental components. Thus, as a result of the different responses of crops to the intrinsic climatic characteristics of each region, studies and research involving crop water demand as well as the development and calibration of lysimeters are necessary.

Besides the determination of crop water consumption and other evapotranspiration studies, lysimeters are also used for the validation of evapotranspiration estimation models and soil water evaporation. Flumignan et al. (2012) used weighing lysimeters to calibrate microlysimeters used in the determination of soil water evaporation.

This study aimed to develop six weighing lysimeters by using high precision load cells and the calibration thereof, testing their ability to measure water mass changes under field conditions in the city of Tangará da Serra, in the state of Mato Grosso.

\section{Material ANd Methods}

The six weighing lysimeters (Figure 1) were built and installed at the State University of Mato Grosso (UNEMAT),

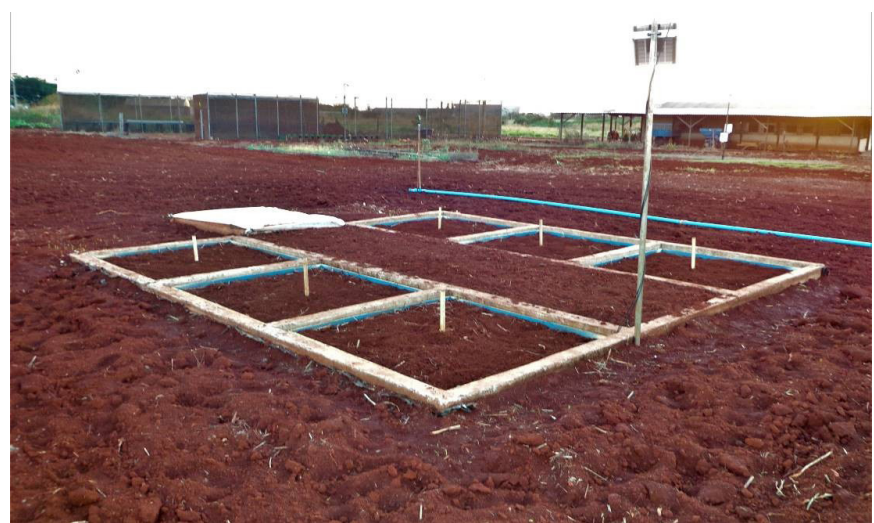

Figure 1. View of all six lysimeters in the experimental area

Tangará da Serra campus - Mato Grosso, located close to an automatic weather station of the National Institute of Meteorology (INMET). The experimental area is located at $14^{\circ}$ $65^{\prime} 00^{\prime \prime} \mathrm{S}$ and $57^{\circ} 43^{\prime} 15^{\prime \prime} \mathrm{W}$, at an altitude of $321.50 \mathrm{~m}$.

For the development and calibration of lysimeters, this study utilized the methodology described by Faria et al. (2006). Each lysimeter contains double rectangular tanks: the outer tank has concrete walls $1.60 \mathrm{~m}$ long, $1.20 \mathrm{~m}$ wide and $1.60 \mathrm{~m}$ deep with a thickness of $0.10 \mathrm{~m}$; the internal tank was built using steel sheets with a thickness of $0.005 \mathrm{~m}$, a square with 1.50 and $1.20 \mathrm{~m}$ deep, and its upper edge was reinforced with $0.035 \mathrm{~m}$ wide corners and the bottom width was reinforced with support beams of $0.040 \mathrm{~m}$, with a crease towards the center of $0.05 \mathrm{~m}$ to facilitate the water drainage system (Figure 2). To prevent leakage and corrosion, the walls of the metal tank were coated with paint.

Each lysimeter was supported by a balance (Balanças Açores, Cambé, PR), which has an "I" beam laminated metal frame of $0.10 \mathrm{~m}$ on top, with the same dimensions of the tank, and at the bottom a force transmission set consisting of four oscillating assemblies connected to a mechanism with three mass reduction levers supported by five bearing brackets fixed on a concrete foundation.

The lever system provides a decreased total mass, which is recorded by Alfa SV 100 load cells with a capacity of $100.00 \mathrm{~kg}+/-50 \%$. The response of the load cells is $2+/-10 \%$ $\mathrm{mV} / \mathrm{V}$, according to the manufacturer. Data storage is achieved by a data collection system, where the output electrical signal from the load cell is connected to a CR1000 datalogger (Campbell Scientific). The electric power of the system is provided by a set of two 12.00 Volts batteries connected to two solar panels, to ensure that there is power supply for the system. Stored data are transferred to a computer using the software PC400.

Each lysimeter was filled with approximately $0.10 \mathrm{~m}$ layer of gravel followed by a water-permeable synthetic fabric. The remainder was filled with local soil removed from pits, following the reverse sequence of excavation in layers to form the original soil.

Each lysimeter was equipped with an accumulated water drainage system at the gravel layer, at the bottom of each tank, consisting of two PVC tubes with a diameter of 0.30 and $1.30 \mathrm{~m}$ long, suspended under the upper frame of the weighing system fixed on metal rods welded on the upper frame (Figure 3 ).

The calibration of lysimeters in field was performed with their surface covered with a plastic sheet to prevent mass 

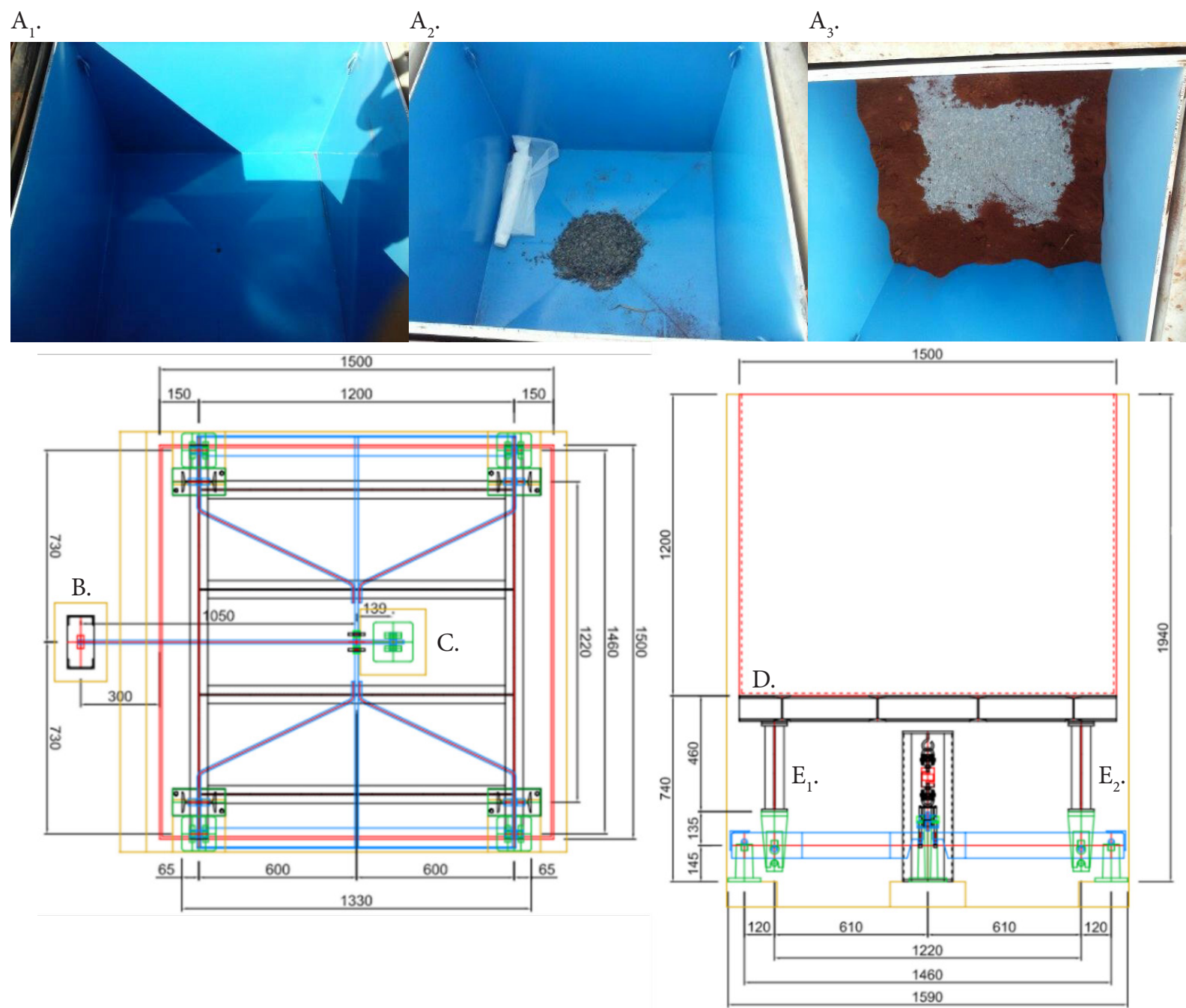

The values in the plan view are in $\mathrm{mm}$

Figure 2. Plan view (left) and lateral view (right) of a set of weight reducing levers and a metal steel box of high precision lysimeters. Metal steel box at different stages of filling ( $A_{1}, A_{2}$ and $\left.A_{3}\right)$, load cell suport (B), central suport (C), metal steel box (D) and metal steel box suport $\left(\mathrm{E}_{1}\right.$ and $\left.\mathrm{E}_{2}\right)$
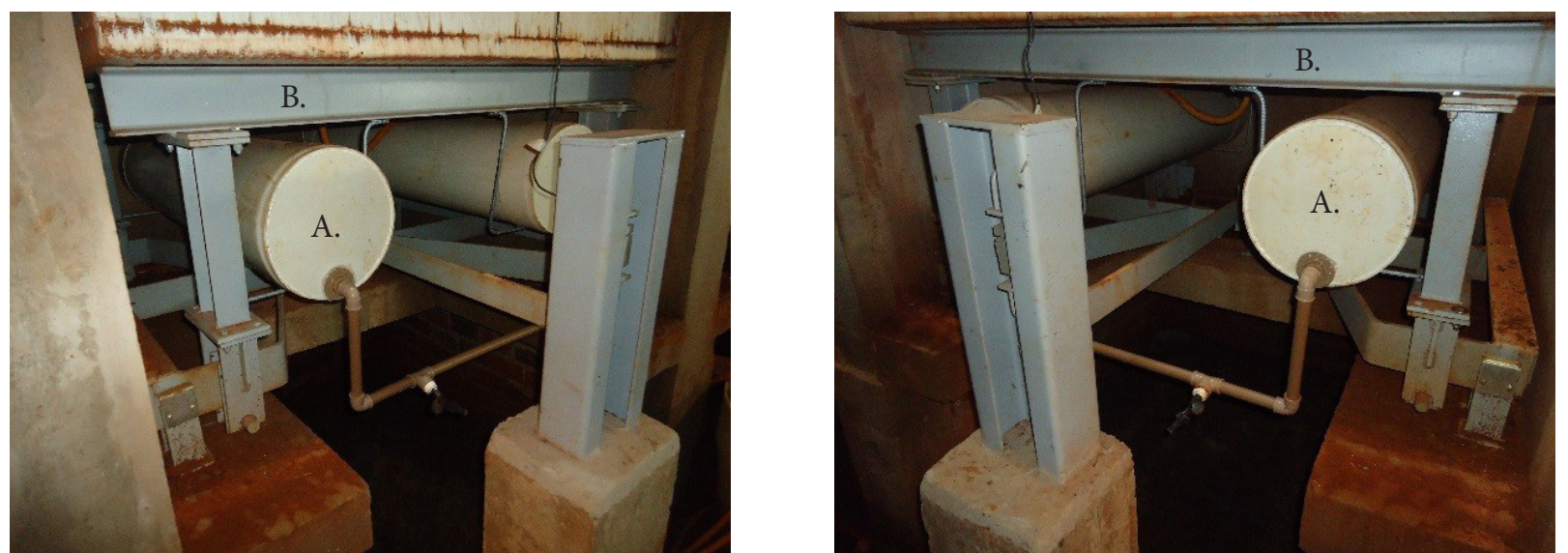

Figure 3. Drainage system (A) of weighing lysimeters fixed on the upper frame (B) of the set of levers

change in the system as a result of the evaporation of water. To avoid the influence of wind during calibration, a windbreak made of plastic sheet with approximately $1.00 \mathrm{~m}$ high was also used around the lysimeters.

The calibration test began with the initial voltage reading of each unloaded lysimeter (with only soil content). The mass change was obtained by the addition and the removal of gravel containing plastic bags of different masses weighed in a resolution balance of $0.01 \mathrm{~g}$. The increases and decreases in mass were read every $2 \mathrm{~min}$ and the readings were taken every $5 \mathrm{~s}$, with an average of $60 \mathrm{~s}$.

The weights were added to the lysimeters in a weight sequence equivalent to $7 \mathrm{~mm}$ of water over the area of the lysimeter $\left(2.25 \mathrm{~m}^{2}\right)$ obtained by adding one gravel bag weighing $15.75 \mathrm{~kg}$ ( $1 \mathrm{~L}$ of water $=1 \mathrm{~kg}$ ) until reaching $70 \mathrm{~mm}$, followed by additions of $1 \mathrm{~mm}$, obtained by adding $2.25 \mathrm{~kg}$ sandbags until 
the mass was equivalent to $80 \mathrm{~mm}$. From $80 \mathrm{~mm}$, the additions were again of $7 \mathrm{~mm}$ until reaching $150 \mathrm{~mm}$. Then, the bags were withdrawn at $2 \mathrm{~min}$ intervals in the same sequence of the addition until completely unloaded, and finally 62 pairs of points were obtained to form a calibration curve $(\mathrm{mV}$ x mm) (Faria et al., 2006). This procedure was performed in four replicates, resulting in 248 data pairs which were subjected to regression analysis and the concordance index of Willmott et al. (1985) to verify the linearity of the system and the presence of hysteresis.

\section{Results AND Discussion}

For the calibration of lysimeters, it is necessary for the soil to be very dry or near the point of permanent wilt. Subsequently, when adding the weights referring to the water slide, the variation of mass is close to the expected when the crop is implanted. If the soil of the lysimeters is high in the calibration, when adding the weights, the mass variation can reach higher levels than the real ones, neglecting the values when water is added to the system.

The lysimeters showed a high correlation between the signal emitted by the load cell and the equivalent weight variation in millimeters. However, they presented hysteresis between loading and unloading operations without jeopardizing their use and the accuracy of measurements. Thus, unloading equations should be used for the monitoring of lysimeters in evapotranspiration studies.

Figure 4 shows the regression analysis and the coefficients for the six sets tested (Figures 4A, B, C, D, E and F). The $\mathrm{R}^{2}$ values near the unit demonstrate a strong correlation between the electric signal output from the load cell and the weight variation of the lysimeter set. Due to the static mass of the set (dead weight), a calibration equation was used for each set, aimed at obtaining a better adjustment of the data and a better accuracy of measurements.

There was variance in angular and linear coefficients between loading, unloading and lysimeters. Such variations are specific to each set due to changes in each set of levers and the mass of each set. These small changes may cause small deviations in the lysimeter coefficients of each set. Such behavior was evidenced by Faria et al. (2006) while analyzing 10 high-precision lysimeters of the IAPAR of Londrina, Paraná state, Brazil, evidencing the importance of using separate equations for each set, seeking a better interpretation of the data collected, and allowing the perception of minor variations in the mass of each set.

All lysimeters showed coefficients of determination higher than 0.99 . Thus, more than $99 \%$ of the variation in the water depth of the lysimeter set can be explained by millivolt readings. The linearity and high coefficients of determination validate the use of lysimeters for evapotranspiration studies. In the sets, small mass changes can be observed. Studies conducted by other researchers also attest to the high accuracy of this lysimeter model. For example, Faria et al. (2006), calibrating 10 lysimeters at the Agronomic Institute of Paraná (IAPAR) in Londrina, obtained coefficients of determination above 0.99 .

Carvalho et al. (2007), calibrating weighing lysimeters in Seropédica, Rio de Janeiro state, obtained a $\mathrm{R}^{2}$ of 0.99 , with
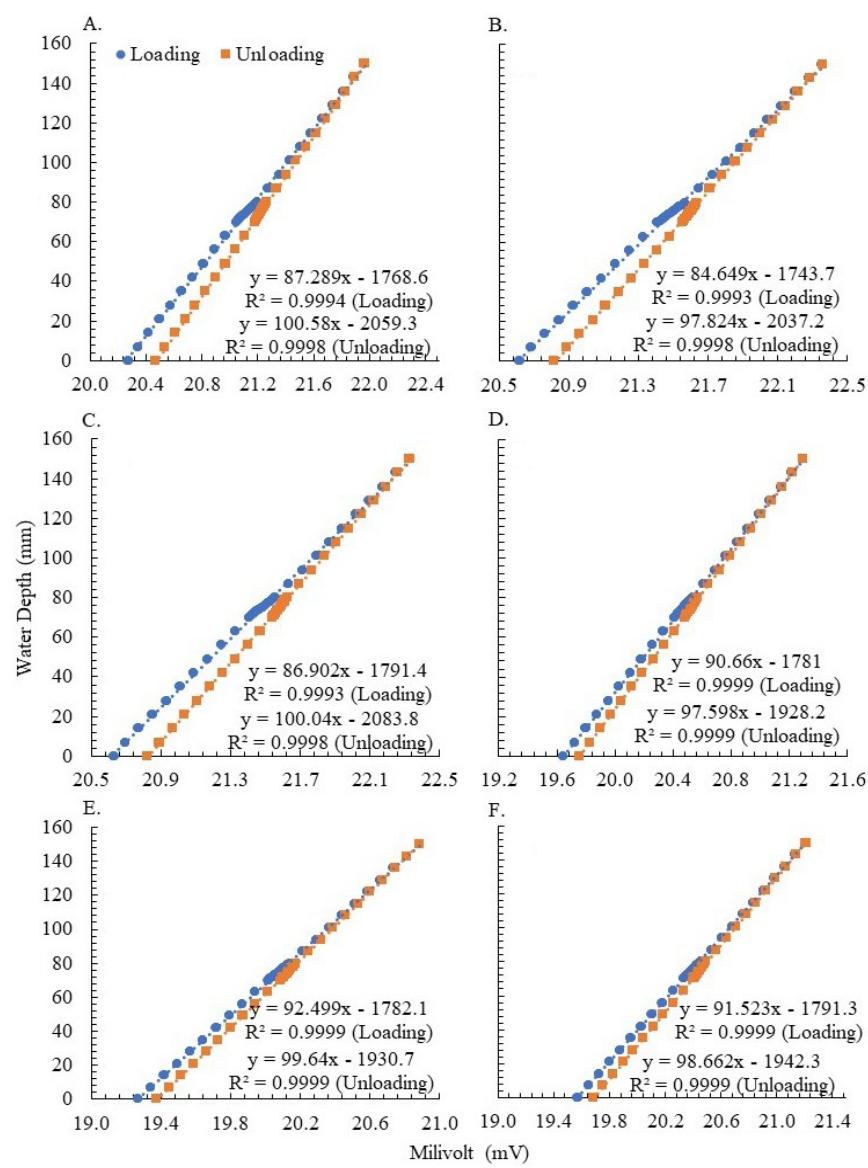

Figure 4. Regression analysis between voltage $(\mathrm{mV})$ and water depth $(\mathrm{mm})$, angular and linear coefficients and coefficients of determination $\left(\mathrm{R}^{2}\right)$ for the six lysimeter $(\mathrm{A}, \mathrm{B}, \mathrm{C}, \mathrm{D}, \mathrm{E}$ and $\mathrm{F})$ sets tested in loading and unloading operations

an average error of $0.28 \mathrm{~mm}$. Mariano et al. (2015), in a study, developed and calibrated 4 weighing lysimeters in the IAPAR of Londrina, PR, and obtained coefficients of determination above 0.99 , with a mass variation sensitivity of $0.15 \mathrm{~mm}$. All tests had negligible system linear responses and hysteresis, demonstrating the reliability of these components to determine evapotranspiration and water balance components. These researches corroborate the results obtained in this study. It is possible to observe differences in the errors and accuracies of measurements attributed to the calibration conditions and methodologies used.

The different results obtained for calibration tests can be attributed to climatic factors such as wind. Due to the high sensitivity of load cells to mass variations, regions with a higher incidence of winds may present different responses during the measurements of lysimeters. However, within standards, they do not alter the reliability of the equipment.

Table 1 presents the errors and the calculated indexes for the lysimeters in loading and unloading operations. The mean absolute error ranged from 0.2273 to 0.8600 , while the mean square error ranged from 0.2759 to 0.9987 . For all lysimeters, the errors were higher in loading than in unloading operations. This is due to the stabilization time of the metal boxes caused by vibrations when bags were added to the calibration test.

Mariano et al. (2015) found a mean absolute error between 0.0245 and 0.2844 , lower than those found in this study. These 
Table 1. Mean absolute error (MAE), mean square error (MSQE), equivalent in millimeters; Willmott index (d), correlation index (r) and confidence index (c) for the six weighing lysimeters

\begin{tabular}{|c|c|c|c|c|c|c|}
\hline \multirow{2}{*}{ Lysimeter } & \multirow{2}{*}{ Operation } & MAE & MSQE & \multirow{2}{*}{ d } & \multirow[b]{2}{*}{ I } & \multirow[b]{2}{*}{ C } \\
\hline & & \multicolumn{2}{|c|}{ equivalent in millimeters } & & & \\
\hline \multirow{2}{*}{1} & Loading & 0.8279 & 0.9630 & 0.9968 & 0.9997 & 0.9965 \\
\hline & Unloading & 0.4121 & 0.5115 & 1.0000 & 0.9999 & 0.9999 \\
\hline \multirow{2}{*}{2} & Loading & 0.8600 & 0.9987 & 0.9983 & 0.9997 & 0.9979 \\
\hline & Unloading & 0.4394 & 0.5316 & 1.0000 & 0.9999 & 0.9999 \\
\hline \multirow{2}{*}{3} & Loading & 0.8516 & 0.9831 & 0.9988 & 0.9997 & 0.9985 \\
\hline & Unloading & 0.4158 & 0.5136 & 0.9999 & 0.9999 & 0.9998 \\
\hline \multirow{2}{*}{4} & Loading & 0.2956 & 0.3578 & 1.0000 & 1.0000 & 0.9999 \\
\hline & Unloading & 0.2592 & 0.3156 & 0.9999 & 1.0000 & 0.9999 \\
\hline \multirow[t]{2}{*}{5} & Loading & 0.3296 & 0.3913 & 0.9999 & 0.9999 & 0.9999 \\
\hline & Unloading & 0.2273 & 0.2759 & 1.0000 & 1.0000 & 1.0000 \\
\hline & Loading & 0.2803 & 0.3532 & 1.0000 & 1.0000 & 0.9999 \\
\hline & Unloading & 0.2897 & 0.3408 & 0.9998 & 1.0000 & 0.9998 \\
\hline
\end{tabular}

differences may be as a result of the different designs or load cell series, small differences in the structure of lever sets, and hysteresis, which can be due to the load cell itself and caused by temperature variations.

The calculated indexes are considered satisfactory for this type of equipment. The indexes $\mathrm{d}, \mathrm{r}$ and $\mathrm{c}$ remained equal or close to the unit in all lysimeters (Table 1), proving the accuracy of the measurements performed by the lysimeters. These indexes demonstrate the reliability of the results of the regression analysis and the coefficient of determination, and attest to the accuracy of lysimeter sets, proving the suitability of this equipment for high confidence measurements. Also, these indexes can be used to assess methods of reference evapotranspiration estimates and crop evapotranspiration.

According to Mariano et al. (2015), indexes close to the unit indicate a good aggregation of mass values in $\mathrm{mm}$ and the electrical signal $\mathrm{mV}$, thus ensuring the accuracy of the measurements of each lysimeter set and indicating that this type of equipment is suitable for water balance studies and estimates of crop evapotranspiration.

In order to evaluate the performance of lysimeters in the field, Figure 5 shows the time variation of lysimeter 1 with irrigation and drainage events in a dual coefficient study on bean crops.

Crop evapotranspiration was determined by lysimeters as $6.47,6.45,5.59$ and $4.67 \mathrm{~mm}$ for the days August 1-4, 2014,

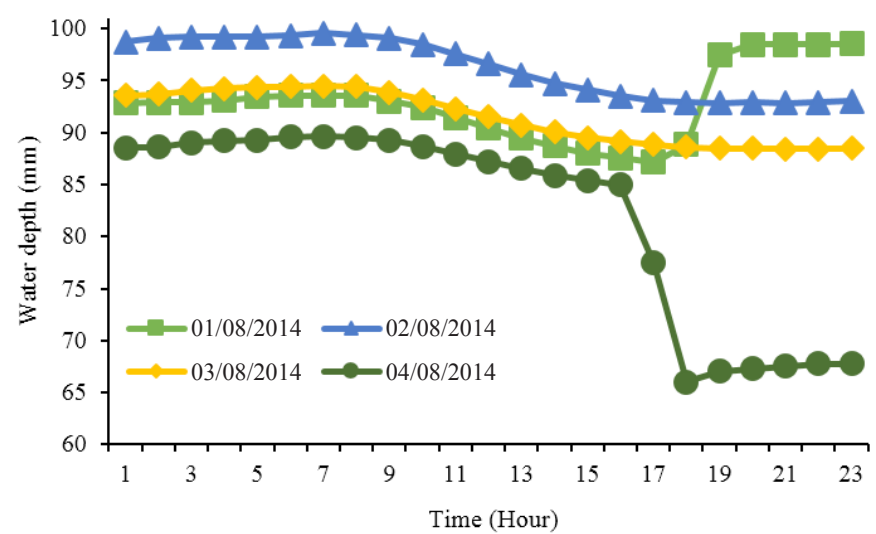

Figure 5. Time variation of a lysimeter during a 4-day period with irrigation and drainage operations respectively. On day $1(01 / 08 / 2014), 11.43 \mathrm{~mm}$ was irrigated, and on day 4 (04/08/2014), $17.94 \mathrm{~mm}$ were drained. The average sensitivity of the lysimeters was $0.12 \mathrm{~mm}$ at one-hour intervals. Thus, the tested lysimeters are suitable for studies on crop water demand, water balance and calibration of evapotranspiration estimation methods.

Campeche \& Aguiar Netto (2007) also evaluated the efficiency of weighing standards in the reference evapotranspiration measure of coconut. They observed that on days when rainfall occurs in periods where there is radiation, it is difficult to define the volume of evapotranspiration and drained volume, requiring a timely observation regarding the rainfall intensity and the water infiltration velocity in the soil. If the volume is greater than the capacity of the box and depending on the wind conditions, it may cause damages and movements of the plants under the lysimeters, thereby resulting to measurement errors.

Nascimento et al. (2011) also reported the need for a manual and visual evaluation of the data to avoid gross errors in the daily determination of evapotranspiration even with automated data collection.

Finally, the six weighing lysimeters showed coefficients of determination above 0.99 , a high sensitivity, a high reliability and high accuracy measurements. Thus, lysimeters are suitable devices for evapotranspiration and water balance studies.

\section{Conclusions}

1. The weighing system of the lysimeters identified $0.12 \mathrm{~mm}$ changes at intervals of one hour. It is not recommended to take measurements at intervals below one hour.

2. The presence of hysteresis was detected primarily for water depths with less than $100 \mathrm{~mm}$ between loading and unloading processes.

3. The use of the unloading equation is recommended for evapotranspiration studies.

4. Each lysimeter presents a calibration equation for the conversion of millivolt to millimeter of water, but the variation of the cell readings is close with values of high accuracy.

\section{ACKnOWLedgements}

The authors express their gratitude for the application and the transfer of technology in optimizing sustainable agricultural systems project, for the financial support provided for the research with process CNPq number: 564112/20100 , notice MCT/CNPq/FNDCT/FAPs/MEC/CAPES/PROCENTRO-OESTE number: 031/2010. The authors also thank the Coordenação de Aperfeiçoamento de Pessoal de Nível Superior (CAPES) for the scholarship granted.

\section{Literature Cited}

Bryla, D. R.; Trout, T. J.; Ayars, J. E. Weighing lysimeters for developing crop coefficients and efficient irrigation practices for vegetable crops. HortScience, v.45, p.1597-1604, 2010. https://doi. org/10.21273/HORTSCI.45.11.1597 
Campeche, L. F. de S. M.; Aguiar Netto, A. de O. A. Desenvolvimento e construção de um lisímetro de pesagem para determinação da evapotranspiração em pomar de coco anão Verde' (Cocus nucifera). In: Congresso Brasileiro de Engenharia Agrícola, 36, 2007, Bonito. Anais... Bonito: SBEA, 2007. CD Rom.

Carvalho, D. F.; Silva, L. D. B.; Guerra, J. G. M.; Cruz, F. A.; Souza, A. P. Instalação, calibração e funcionamento de um lisímetro de pesagem. Engenharia Agrícola, v.27, p.363-372, 2007. https://doi. org/10.1590/S0100-69162007000300005

Cavalcante Júnior, E. G.; Medeiros, J. F. de; Melo, T. K. de; Espinola Sobrinho, J. E.; Bristot, G.; Almeida, B. M. de. Necessidade hídrica da cultura do girassol irrigado na Chapada do Apodi. Revista Brasileira de Engenharia Agrícola e Ambiental, v.17, p.261-267, 2013. https://doi.org/10.1590/S1415-43662013000300003

Evett, S. R.; Howell, T. A.; Schneider, A. D.; Copeland, K. S.; Dusek, D. A.; Brauer, D. K.; Tolk, J. A.; Marek, G. W.; Gowda, P. H. The Bushland weighing lysimeters: A quarter century of crop ET investigations to advance sustainable irrigation. Transactions of the American Society of Agricultural and Biological Engineers, v.59, p.163-169, 2015. https://doi.org/10.13031/trans.58.11159

Faria, R. T.; Campeche, L. F. de S. M.; Chibana, E. Y. Construção e calibração de lisímetros de alta precisão. Revista Brasileira de Engenharia Agrícola e Ambiental, v.10, p.237-242, 2006. https:// doi.org/10.1590/S1415-43662006000100035

Flumignan, D. L.; Faria, R. T. de; Lena, B. P. Test of a microlysimeter for measurement of soil evaporation. Engenharia Agrícola, v.32, p.80-90, 2012. https://doi.org/10.1590/S0100-69162012000100009

Howell, T. A.; Schneider, A. D.; Jensen, M. E. History of lysimeter design and use for evapotranspiration measurements. International Symposium on Lysimetry for Evapotranspiration and Enviromental Menasurements, 1991, Honolulu. Proceedings... Honolulu: American Society of Civil Engineers, 1991.p.1-9. http:// cedb.asce.org/cgi/WWWdisplay.cgi?72381
Lopes, O. D.; Kobayashi, M. K.; Oliveira, F. G.; Alvarenga, I. C. A.; Martins, E. R.; Corsato, C. E. Determinação do coeficiente de cultura $(\mathrm{Kc})$ e eficiência do uso de água do alecrim-pimenta irrigado. Revista Brasileira de Engenharia Agrícola e Ambiental, v.15, p.548553, 2011. https://doi.org/10.1590/S1415-43662011000600002

López-Urrea, R.; Montoro, A.; Mañas, F.; López-Fuster, P.; Fereres, E. Evapotranspiration and crop coefficients from lysimeter measurements of mature "Tempranillo" wine grapes. Agricultural Water Management, v.112, p.13-20, 2012. https://doi.org/10.1016/j. agwat.2012.05.009

Mariano, D. de C.; Faria, R. T. de; Freitas, P. S. L. de; Lena, B. P.; Johann, A. L. Construction and calibration of a bar weighing lysimeter. Acta Scientiarum. Agronomy, v.37, p.271-278, 2015. https://doi. org/10.4025/actasciagron.v37i3.19368

Matušek, I.; Reth, S.; Heerdt, C.; Hrčková, K.; Gubiš, J. Lysimeter: A unique tool for monitoring the interactions among the components of environment. Proceedings of National Aviation University, v.67, p.69-75, 2016. https://doi.org/10.18372/2306-1472.67.10436

Nascimento, E. F. do; Campeche, L. F. de S. M.; Bassoi, L. H.; Silva, J. A.; Lima, A. C. M.; Pereira, F. A. de C. Construção e calibração de lisímetros de pesagem para determinação da evapotranspiração e coeficiente de cultivo em videira de vinho cv. Syrah. Irriga, v.16, p.271-287, 2011. http://revistas.fca.unesp.br/index.php/irriga/ article/view/286/174

Talebnejad, R.; Sepaskhah, A. R. Effect of different saline groundwater depths and irrigation water salinities on yield and water use of quinoa in lysimeter. Agricultural Water Management, v.148, p.177-188, 2015. https://doi.org/10.1016/j.agwat.2014.10.005

Willmott, C. J.; Ackleson, S. G.; Davis, R. E.; Feddema, J. J.; Klink, K. M.; Legates, D. R.; Rowe, C. M. Statistics for the evaluation and comparison of models. Journal of Geophysical Research: Oceans, v.90, p.8995-9005, 1985. https://doi.org/10.1029/ JC090iC05p08995 